\title{
Factors, challenges and obstacles for internationalization of Romanian agro-food products
}

\author{
Ionut SARACUTU \\ Bucharest University of Economic Studies, Bucharest, Romania \\ saracutuionut@yahoo.com
}

\begin{abstract}
The world-wide process of structural transformation is a result of the emergence of new challenges with long-term effect; which requires a strategic vision in the agro-food trade, together with the implementation of concrete actions by the authorities. Increasing global population, increasing pressure on natural resources and global warming are leading to a new framework at international level. In Europe, the aging process is an additional challenge. All these aspects will have profound implications for agriculture and rural areas. Global food demand is increasing, a large scale of urbanization, rising input prices, pressure on water resources and increasing vulnerability of crops and animals to climate change will limit food production.

Even in these conditions agricultural sector of Romania has a huge potential. Domestic food demand could be covered if this potential will be exploited with technological resources and would not depend so much by climatic factors. Also Romania could export significant quantities of agro-food products. On the other hand, Romania suffers from one of the most pronounced structural divisions of agricultural land between all EU member states and also between the new member states. Precisely for this reason, Romania loses a lot in terms of production and export of agro-food products, in competition with developed countries. This paper analyzes the competitive position of Romanian companies in agro-food value chains. The article also answers to one of the most important questions. Are Romanian companies competitive in the agro-food value chains? What are the factors, challenges and obstacles for internationalization of Romanian agro-food product? In order to answer these questions, a quantitative research was performed using statistical data obtained from International Trade Center, for the year 2019 and Romanian National Committee for Macro prudential Supervision, 2020.
\end{abstract}

Keywords: agro-food, agriculture, trade, value chains, development, challenges, competitive advantage, comparative advantage.

\section{Introduction}

Agriculture is still an important sector in Romania, in relation to the size of the rural population and the degree of employment. Approximately $45.7 \%$ of the Romanian population lives in rural areas, compared to approximately $23.6 \%$ in EU member states. About $30 \%$ of the population is employed in agriculture compared to about 2\% in the old Member States (EU15) and 3-14\% in the Member States (EU-18). There are important differences between rural and urban areas, the first having a higher level of poverty and automatically a lower standard of living. The development of agriculture through the adoption of concrete measures is more than essential for the European integration of Romania and for the achievement of the objectives of social cohesion. (Ministry of Agriculture, 2015). (Antimiani, Carbone, Constantini and Henke, 2012) consider that "the economic integration of Central and Eastern European countries into the European Union has been a major challenge for both, the old Member States and the new Member States in many ways". The Western countries gained a new cheap labor force, as well as quality products at a low price, and the Central Eastern countries had the new market for the exports of their products. In Romania, the decrease of agricultural labor productivity is the result 
of the combined effects of labor market trend and market failures. Emigration is a major threat because there are no more agricultural workers (Ciutacu, Chivu, Andrei, 2014). With Romania's accession to the European Union, the flow of goods to and from the country has changed. Removal of customs barriers to trade in the European Union allowed free movement of goods and services (Şerbănel, Cojanu, 2016). According to Economic Statistics (2020), Romania registered an increase of exports from 18,935 million Euros (2004) to 69,002 million Euros, in (2019). According to Eurostat (2018), Romania in 2018, from the total exports has exported 75.8\% Intra EU-28 and 24.2\% Extra EU-28. Significantly higher values were achieved in the post-accession period, and in 2013 it reached a value of 7 billion USD, 6 times higher than in 2006 and 12 times higher than in 2003. Achievements in the first two years after Romania's accession to the EU were significantly better compared to 2006, the last year before EU accession. More precisely, the value of trade in Romanian agri-food products has doubled. With the increase of exports, after the accession to the EU, imports also increased, but at a lower level compared to exports - 3.6 times in the periods 2003-2013 according to Bułkowska (2015). Regarding the top countries where Romania exports goods: France, Germany, Italy and the United Kingdom absorb 57\% of exports of goods and services from Romania to the European Union, and 44\% of total exports (approximately 37.2 billion euros during 2018), resulting in a trade surplus of 3,8 billion euros compared to these countries. The main European market for Romanian producers of goods is Germany. Approximately 30.1\% of Romania's total exports of goods to European Union countries are destined for German consumers (Council Competition, 2019). This market is followed, as value of exports from Romania, by Italy (12.2\%), France $(9.6 \%)$ and Hungary $(6.6 \%)$.

According to SITC classification (Revision 3) there have been changes produced in Romania's foreign trade. It was found that, compared to 1995 the first available year of the data series in UNCTAD statistics, in 2016 Romania gained positions in 46 exports of 180 product groups. A special remark is required for the exports of cereals (group 044- corn and respectively 041-wheat), which registered a gain of 7 positions, Romania being in 2016 on the 7th and respectively on 9th places, in the top of the world exporters at these products (Zaman and Georgescu 2018). The main attributes of this paper consist from the way is systematizing the information. Theoretical aspects are supplemented with examples, statistical data and comparative data. This article aims to investigate the factors, challenges and obstacles for the internationalization of Romania's agro-food product. The geographical concentration of farming activities helps technological development, innovation, sharing resources and information, aspects that lead to increased farmers' incomes. (Dadan, Ihle and Heijman, 2017). In Romania, agro-food clusters are divided in the most regions of the country. According to Porutiu (2020) the aim of Romanian clusters is to create a regional brand of agro-food products and to be known nationally and internationally. According to Figiel, Kuberska and Kufel, (2012) in EU member states the agri-food sector is not so important because it does not contribute to total gross value added, rather having the role of employment and improving the outcome of total output.

This research also is analyzing and compares competitive position of Romania in agrofood value chains, in 2019. The measures necessary to increase the competitiveness of the agricultural sector and to ensure food security must take into account the needs and profile of the Romanian consumer. The last years have been defined by an alignment of the habits, preferences and quantities required by the European citizen. However, this phenomenon puts pressure on local production which cannot maintain the same speed of development as that of the appetite for consumption. 


\section{Literature review}

"Agriculture before anything else, has been the architect and builder of social, cultural, moral, linguistic, aesthetic, and artistic structures of the world's nations" (Ciutacu, Chivu, Andrei, 2014). Over the years, but still in present, in some parts of the world agriculture has made known to people the economic concepts surrounding trade, such as goods, fairs, costs, profit, suppliers and customers. These social and economic processes, with their institutional components have been strongly determined during their development by the relationship between the population and the inhabited land, in terms of extent and form of ownership (Ciutacu, Chivu, Andrei, 2014). Due to an inadequate development and implementation of information systems in the agricultural sector, the capacity of technology information cannot be fully exploited and the degree of sharing information between members of value chains will be low. As a result, upstream farmers rarely get accurate information on demand from downstream supply chains and the supply of primary agricultural products can often not meet the requirements of local businesses. In addition, the low level of information sharing makes downstream customers less informed about product information for local businesses, which in turn reduces customer confidence in product quality and leads to poor sales (Zhao, Wang, Pal, 2020). This is one of the main problems of China in terms of value chains of agricultural products, but fortunately this is not a problem anymore in Romania, which in terms of information has seen real progress due to good development in terms of information technology at the country level, generally. Instead Romania suffers from the point of view of the development of the agricultural infrastructure through a weak irrigation network and because of the fact that agricultural crops are divided. Romania is still in the market segment with a low quality of its agro-food products, with a competitive performance in an abruptly fall that causes trade deficit of this sector that is growing yearly. Firms that export agro-food products have a relatively low importance in the economy. The companies which exports agricultural goods, respectively the companies that carry out exports of goods in the food industry are small in number (approximately 1000 companies in both categories) and they do not have a high importance in the economy in terms of the number of employees and in terms of contribution to gross value added, generated at the level of the non-financial companies. Thus, companies that export agricultural goods employ over 133,000 employees ( 3 percent) and generate 4 percent of gross value added and in the case of companies that export products from the food industry, the number of employees is about 183,000 (4.5 percent), and the contribution at gross value added is 5.3 percent (Romanian National Committee for Macro prudential Supervision 2020). From the perspective of the financial position (profit and loss) of companies that export agro-food products, the indicators show that they have a satisfactory financial health at the balance sheet submitted in 2018. The profitability level of these companies is relatively high, the degree of indebtedness is adequate and liquidity indicators show a satisfactory capacity (supraunitary) in case of liquidity pressures. Debt service ratio is at a good level and the liability structure of these companies also shows that they are well capitalized, the share of capital in total liabilities being higher than the average of the financial companies in general. (Romanian National Committee for Macro prudential Supervision 2020).

According to (Bojnec and Ferto 2009) competitiveness can be analyzed at three levels: company level, national level, and international level. Another aspect of competitiveness refers to the geographical and spatial dimension of the investigation; comparisons are made between companies or trade between a country and a region of a particular country or between countries. Competitiveness at national level is measured by the concept of comparative advantage. The comparative advantage theory demonstrates that trade flows are a result of the relative cost 
difference between trading partners. Specifically, countries are competitive in trade only if they have a relatively cost advantage. The main difference between comparative advantage and competitiveness is market distortion. In the case of comparative advantage this distortion is not valid. In the agricultural or agro-food markets we find policy distortion and that competitiveness gives us a much more realistic image of the world (Barkema et all., 1991). From another perspective, regarding the difference between comparative advantage and competitiveness Lafay in 1992, points out two additional differences. First of all, in order to determine the competitiveness, an analysis between two or more countries is required for a particular product. Instead, the comparative advantage is measured by an analysis between products from a single country. "Secondly, competitiveness is subject to changes in macroeconomic variables, while the comparative advantage is structural in nature" (Lafay 1992). Finally, it is considered that both, comparative advantage and competitiveness are supported by the concept of balance, in which all the interdependencies from an economy can be taken into account.

\section{Methodology}

The research methodology follows competitive and comparative analysis. The competitive and comparative analysis enables companies to take various factors into account when they are creating a project, investment plan. With the help of Trade Statistics for International Business Development as visualization, maps in the form of directed graphs and spring-embedded layout could be created and the filter countries could be observed. Methods are focused on understanding phenomenon in a comprehensive and holistic way. Methodological approach for investigating the research it is a quantitative method. In order to accurately assess the degree of dependency and pattern of trade flows worldwide, the method identified countries that are in close trade relations with Romania in terms of global exports of agro food, at 2-digit categories of products. Articles and statistics date are recent and collected from international databases (International Trade Center) for the year 2019 and (Romanian National Committee for Macro prudential Supervision) made in 2020. The data is free for public access and the creation of a free user account is required. In order to analyze the factors, challenges and obstacles for the internationalization of Romanian agro food products, data obtained from the International Trade Center were used. These data show that the agro food sector is one of the sectors that produce an annual deficit in Romania's trade balance. By exporting basic products and not processing them, Romania loses a lot in trade balance. The article also makes an analysis of the general situation of the agro-food sector in Romania and highlights the disadvantages and advantages of this industry. Although significant improvements have been made in recent years, especially after EU accession, the agro-food industry requires additional and major investments in order to be competitive in an increasingly market. It is necessary for Romania to improve production, to increase the agricultural area and to acquire advanced technology. The article brings together an analysis of processed food and agro based products sectors. There will be presented top 15 countries where Romania exports and top 15 countries from where it imports this category of products, together with situation of trade balance in 2019. Secondly will be analyzed the largest trade surplus of basic agro food products, the cereals and live animals and the agro food sectors with the largest trade deficit, meat and edible meat offal and edible fruit and nuts; peel of citrus fruit or melons. The analysis will be made from the point of view of Romania's position at global level, in terms of imports and exports and from the point of view of the global market share and the growth rate. 


\section{Results and discussion}

Although Romania has an advantage in the agricultural field being the country with the sixth largest area of agricultural land in the EU and one of the largest producers of cereals in the EU, it has a very low productivity, largely due to structural problems that they have accumulated for decades. According to the data collected Romania's exports of processed food and agro based products are mainly directed to the countries from the European Union. As can be seen in (Figure 1) presented below, top 3 importers of Romanian agro based products are Italy, Bulgaria and Germany. The value exported to these 3 countries is over 1 billion Euros. The only country outside the European space that is in top 15 is Japan, which is one of the largest importers of agro-food products worldwide. In the top of exports by products we find food preparations, pastries and crude sunflower-seed or safflower oil. Romania's variety in the processed food and agro-based products sector is poor. Romanian companies in the food sector prefer to channel all their attention and all their business on the local trade for safety reasons, historical partners, a basic commercial network and human resources. It has been observed in the last years that Romanian companies from the food industry produce more for the own brand of key accounts. Although the payment term offered by these large clients sometimes exceeds 90 days, Romanian small and medium companies prefer such a business, because key accounts offer them security and a good price, and this very large gap is covered by credit facilities from banks, like working capital or factoring. However, banks and financial institutions could help companies in the agrofood sector much more. Lending to companies from the agricultural sector has increased and has been intensely promoted in the last 10 years, but companies from the food sector have not, because they don't have a strong need for working capital lines and managed to support it from their own sources. Both, companies from agricultural sector and companies from food sector need financing in terms of investment projects. Investment projects bring added value to companies' business by improving production capacity, by a lower production costs and by reducing staff costs. Although agricultural firms have received a significant amount of credit from banks, the European Commission and the European Investment Bank show that there is a significant funding gap for Romania's agriculture, estimated between 2.2 billion euros and 5.3 billion, especially for long-term lending needs.

Figure 1. List of importing markets for a product group exported by Romania. Product group: Processed food and agro based products

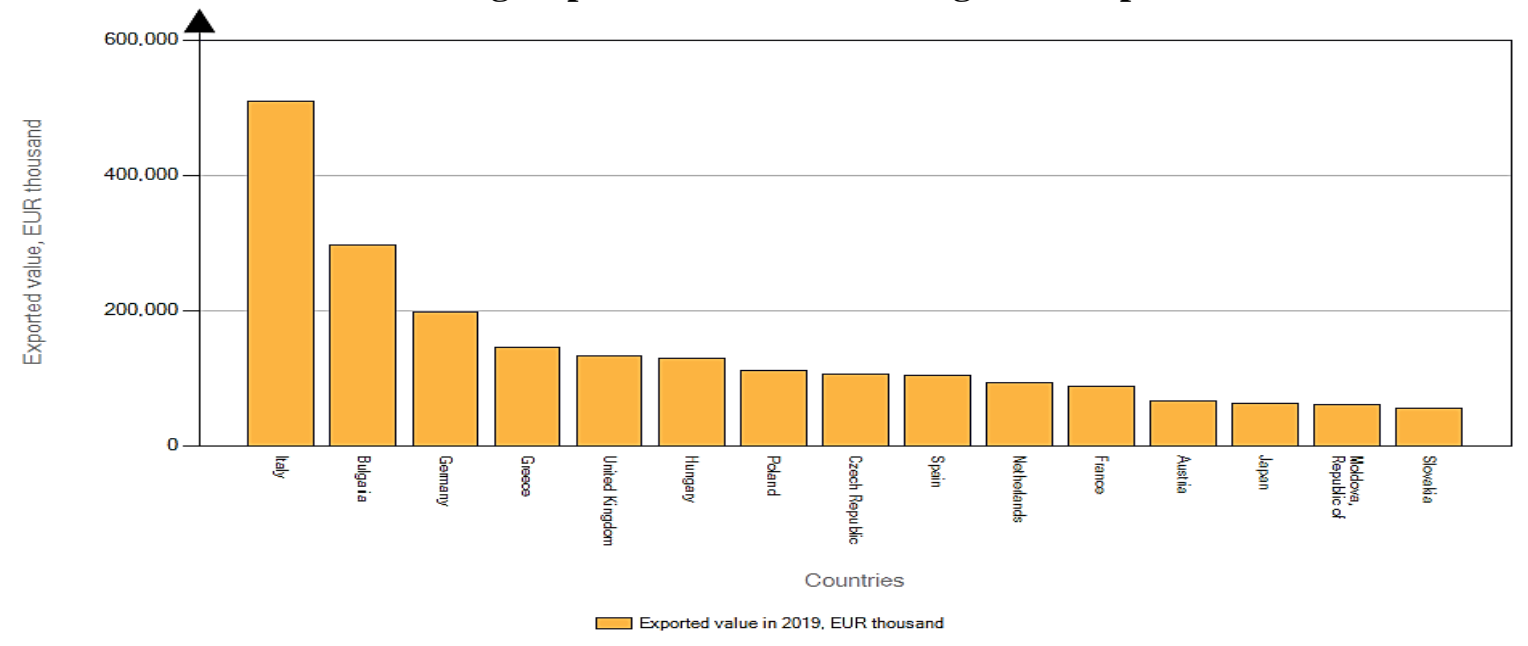

Source: trademap.org, 2021. 
Regarding the imports of agro-food products, Romania imports large quantities from Germany, Poland, Hungary and Italy (Figure 2). Only from these 4 countries imports products worth over 2.3 billion Euros. In 2019 Romania paid for imports of agro-food products, large amounts, in case of meat imports, approximately 800 million Euros, bakery and pastry products 370 million Euros, Chocolate 330 million Euros, cheese 283 million Euros and coffee 216 million Euros. The potential development of companies from agro-food sector is affected by imports, in the context of a structural competitiveness deficit, including for categories of domestic products available. In the last decade Romania produces for the external market agro-food with low added value and imports products with higher added value. Specifically, Romania export basic agricultural products and import finished products. Also Romania is at a disadvantage at European level in terms of innovation in agriculture and processed food. Only $1 \%$ of the companies that are operating in the agro-food sector are using industrial robots. Secondly, due to the good telecommunications infrastructure, easy access to a fast internet, numerous IT specialists, the support provided by the state to the IT sector, the opening of companies and the population in assimilating digital technologies, Romania has the opportunity to progress and to move to the widespread use of digital technologies in agriculture and the food industry. Certainly, with the help of digital technology, part of the disadvantage of the pronounced fragmentation of agricultural lands in Romania could be canceled.

Figure 2. List of supplying markets for a product group imported by Romania. Product group: Processed food and agro based products

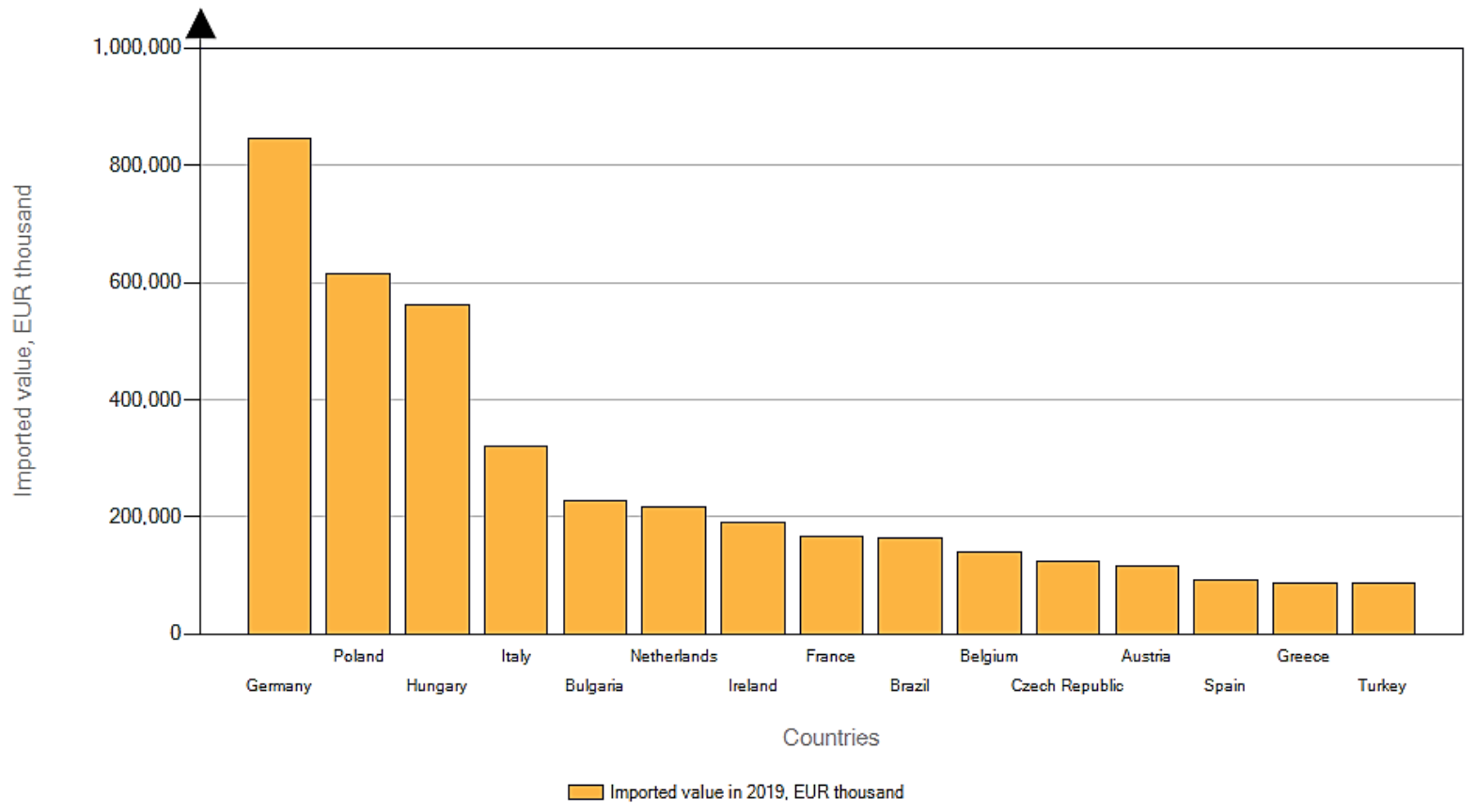

Source: trademap.org, 2021.

Regarding the agro-food products in 2019, registered a deficit worth 1.9 billion Euros. This minus comes from the trade of food preparation, chocolate, cakes, sugar, whiskeys and many others, generally from final products. As can be seen below in Figure 3, the trade deficit comes from imports of agro-food products from countries such as Germany, Hungary, Poland, the Netherlands, France, Austria and other European countries which have a well-defined system 
in terms of semi-prepared or prepared food. Once added, this increase from 2019, plus the annual deficit increases starting with 2015, the trade deficit with agro food products has become significant (4.3 billion euros in December 2019) doubling in the last five years. This deficit is partially mitigated by the surplus of foreign trade with cereals. In 2019, the export of cereals registered a significant share of Romania's agro-food exports, 50\%. In terms of structure, persistent surpluses are mainly from international trade of cereals, where there has been an improvement in the balance from around $€ 1.6$ billion in 2013 to $€ 2.2$ billion in 2019 . In the case of trade of live animals, a surplus was also recorded, but the values are considerably lower (150 million euros in 2013 increasing to 253 million euros in 2019). Regarding products of agrofood industry, there are deficits in all sectors. In the case of meat, vegetables and fruits, the deficits increased more than 2.5 times in the period 2013-2019. Cereals based on food and beverages showed smaller but significant increases, 1.7 times for the first category and 2.2 times for the second category. Overall, the trade balance in agro-food products has become a potentially systemic vulnerability for at least three reasons: (i) the existence of a close relationship between the deterioration of the current account deficit and the balance payments crisis; (ii) the need to ensure food security and (iii) Low productivity in agriculture (Romanian National Committee for Macro prudential Supervision 2020).

Figure 3. List of partners markets for a product group commercialized by Romania. Product group: Processed food and agro based products

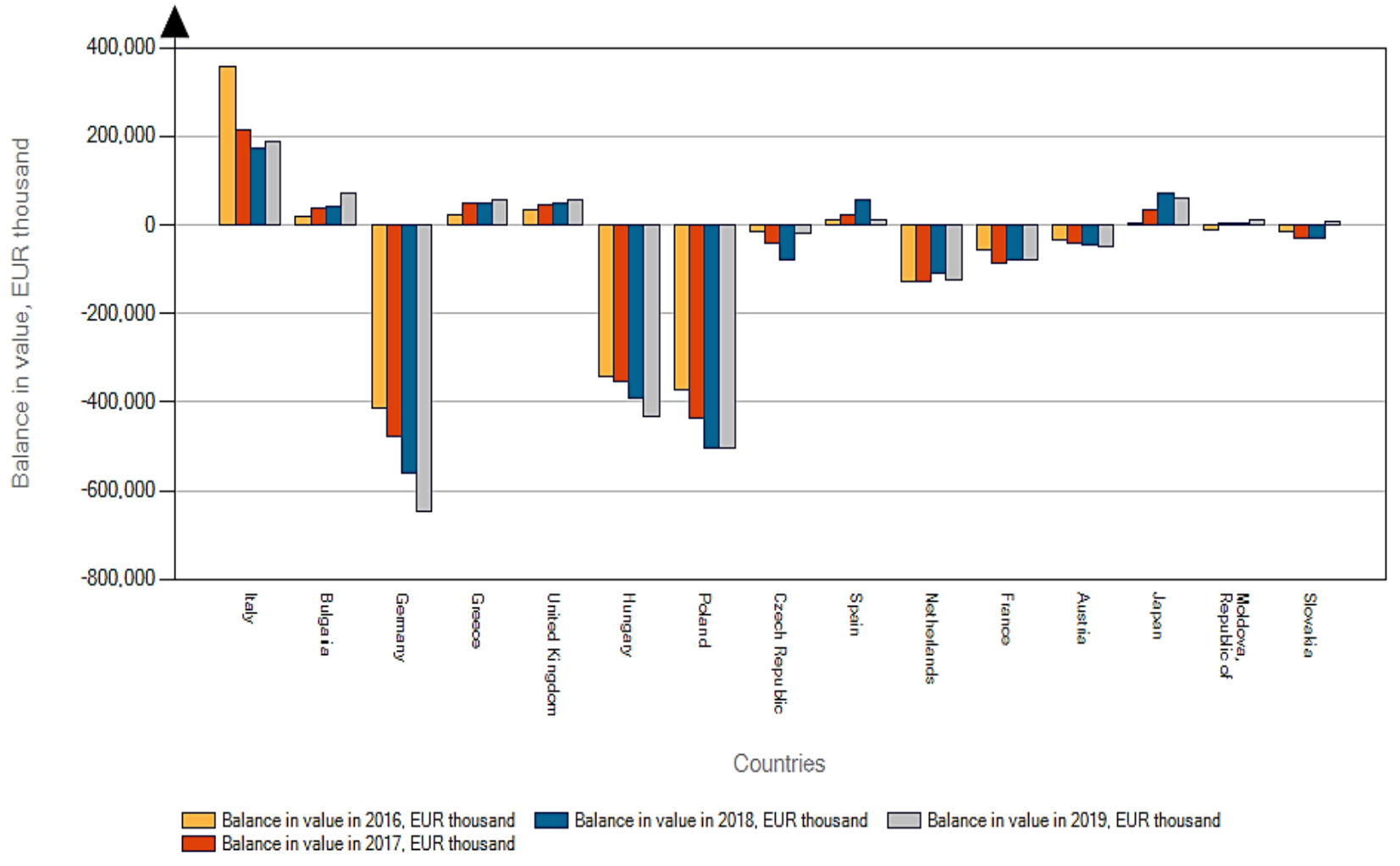

Source: trademap.org, 2021.

In the next section of the article will be analyzed the growth of Romania's exports to the top 30 partners in the period 2015-2019. The top 30 countries were selected, which represent a percentage of at least $0.1 \%$ of the total exports/imports on the respective product. Two groups of 
products were selected where Romania has an important surplus; cereals and live animals sector and two sectors with the largest deficit registered in 2019 (Meat and edible meat offal and Edible fruit and nuts; peel of citrus fruit or melons). With yellow bubble we have Romanian export growth to partner < Partner import growth from the world, and with blue bubble we have Romania export growth to partner > Partner import growth from the world. The bubble size is proportional to the share in world imports of partner countries for the selected product.

Italy and Germany are Romania's partners with the biggest share in importing of live animals. Together they represent globally $15.43 \%$ of the import of live animals. The graph shows an increase of Romanian's exports to Germany, $16 \%$, but also to Italy, where the percentage is $4 \%$. If the increase of German imports of this product is only $2 \%$ annually, in the case of Italy the increase is $4 \%$, which means that Romania has a much higher growth of exports to Germany compared to the annual growth of Germany imports. The increase of Romania's exports to Italy is in line with their increase of imports in terms of live animals. Romania registered increases in exports of live animals to Turkey, Iraq, Kuwait, United Arab Emirates, Hungary, but has lost in case of Spain, Poland, Bulgaria, and Israel.

\section{Figure 4. Growth in demand for a product exported by Romania in 2019. Product: Live Animals}

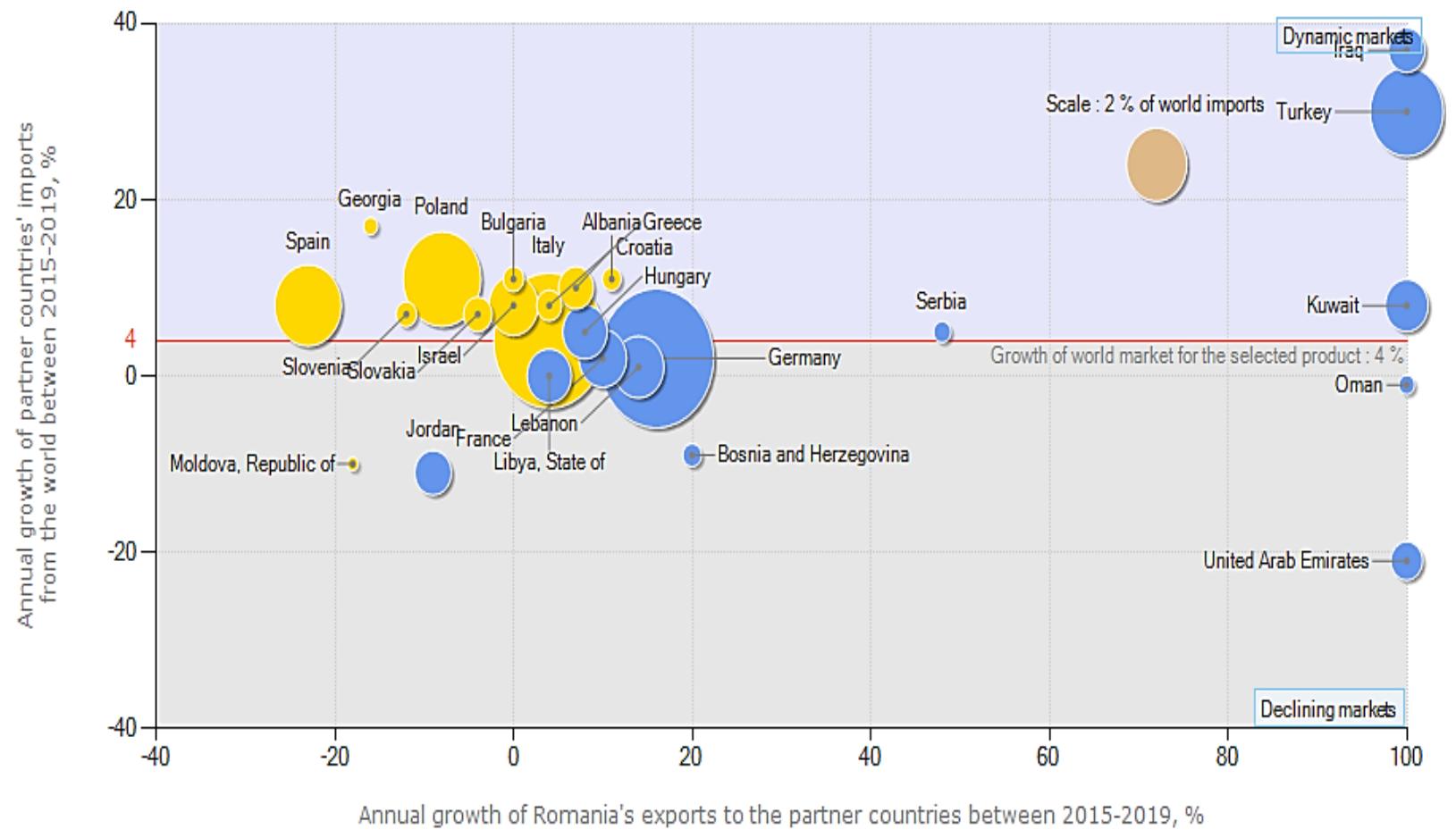

Source: trademap.org, 2021.

In the case of cereals exports (Figure 5), Romania lost in relationship with Japan where it registered a decrease of $60 \%$, Tunisia $-22 \%$ and Korea $-10 \%$. But at the same time it registered significant increases of exports to partners like Germany 64\%, Turkey 25\%, United King 29\%, Italy $23 \%$, France $10 \%$ and Thailand with an increase of over $200 \%$. Romania's gains in terms of cereals exports are the fact that the partners represented with blue bubble and yellow bubble close to axis 0 have an important percentage worldwide, in terms of cereals imports (over 25\%). The 
Romanian agricultural sector is too much dependent on the climate and has very large annual fluctuations in production, precisely for this reason. Apia grants are not enough for local farmers, as the amounts received through this program represent very low level from companies' annual expenses. Romania's capacity to export cereals is much higher than it currently achieves and only concrete measures can help to a larger production capacity.

Figure 5. Growth in demand for a product exported by Romania in 2019. Product: Cereals

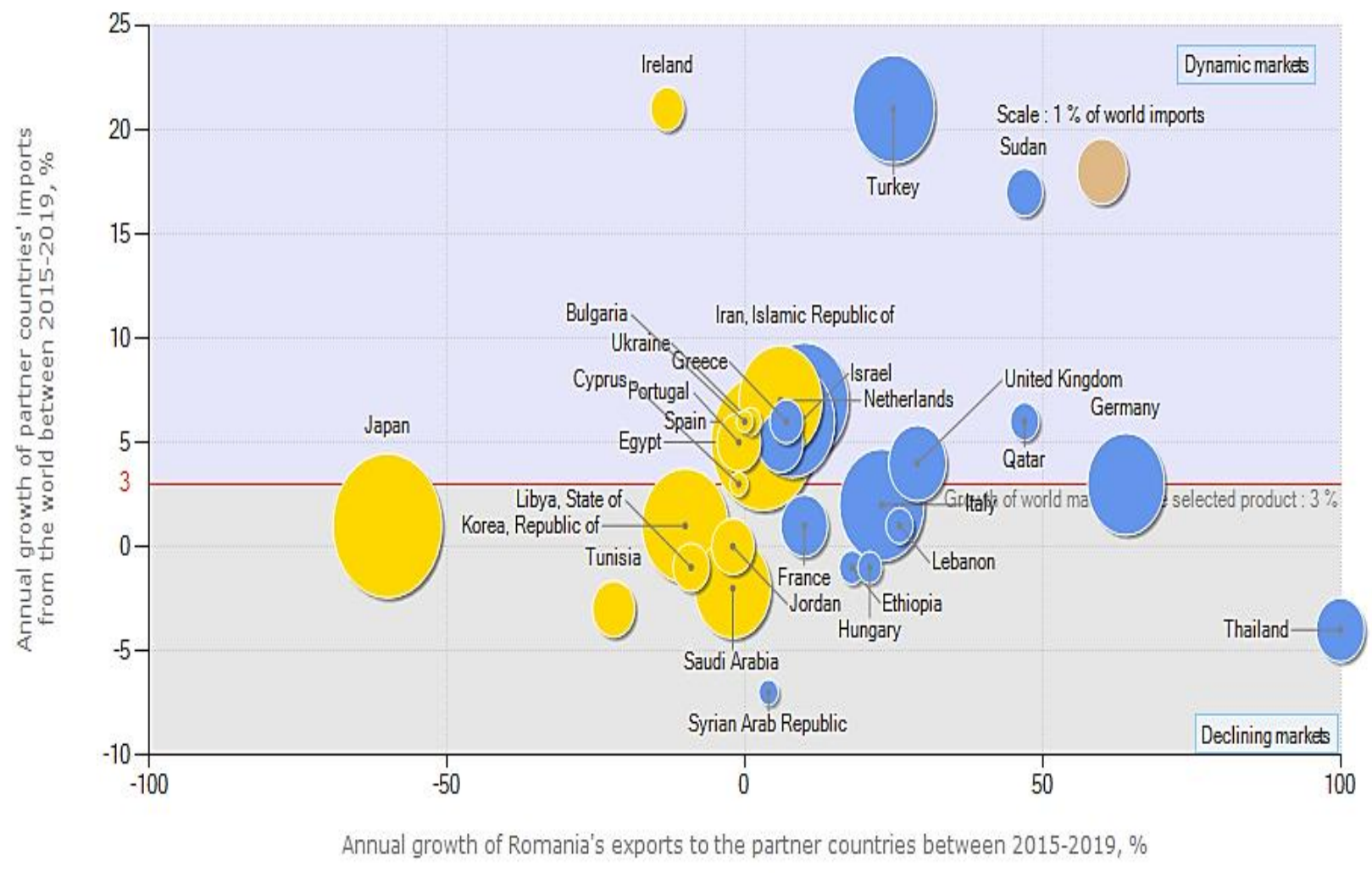

Source: trademap.org, 2021.

Visually we can observe a much higher concentration beyond the 0 axis of the yellow bubble for figure 5 and 6 . Romania registers important decreases in terms of exports of these products sectors. The deficit of over 1 billion Euros can be seen in the figures below. The trade deficit comes from the relationship with partners such as the USA, France, Belgium, Slovenia, and Germany. The only countries where we record the largest increases are Japan, Italy, England and the Netherlands, Sweden, United Kingdom and Portugal. The decrease of exports to the EU members means a much higher impact for Romania, because this aspect means that this country is losing field in front of its competitors from the vicinity. Regarding edible fruit and nuts could export huge quantities of such products, due to its large area, soil and favorable climate. For example, Poland exports large quantities of such products even to Romania. 
Figure 5. Growth in demand for a product exported by Romania in 2019.

Product: Meat and edible meat offal

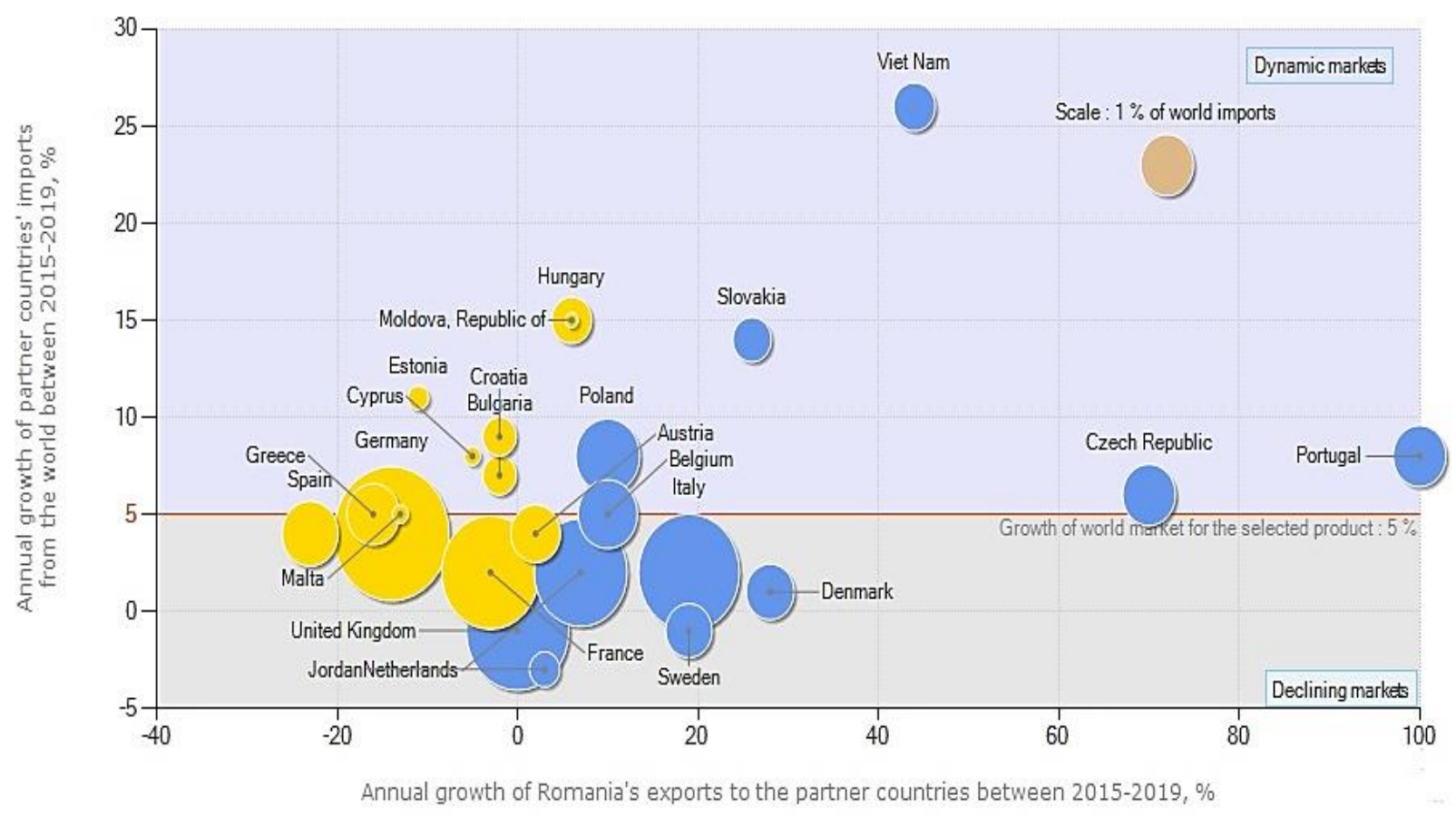

Source: trademap.org, 2021.

Figure 6. Growth in demand for a product exported by Romania in 2019. Product: Edible fruit and nuts; peel of citrus fruit or melons

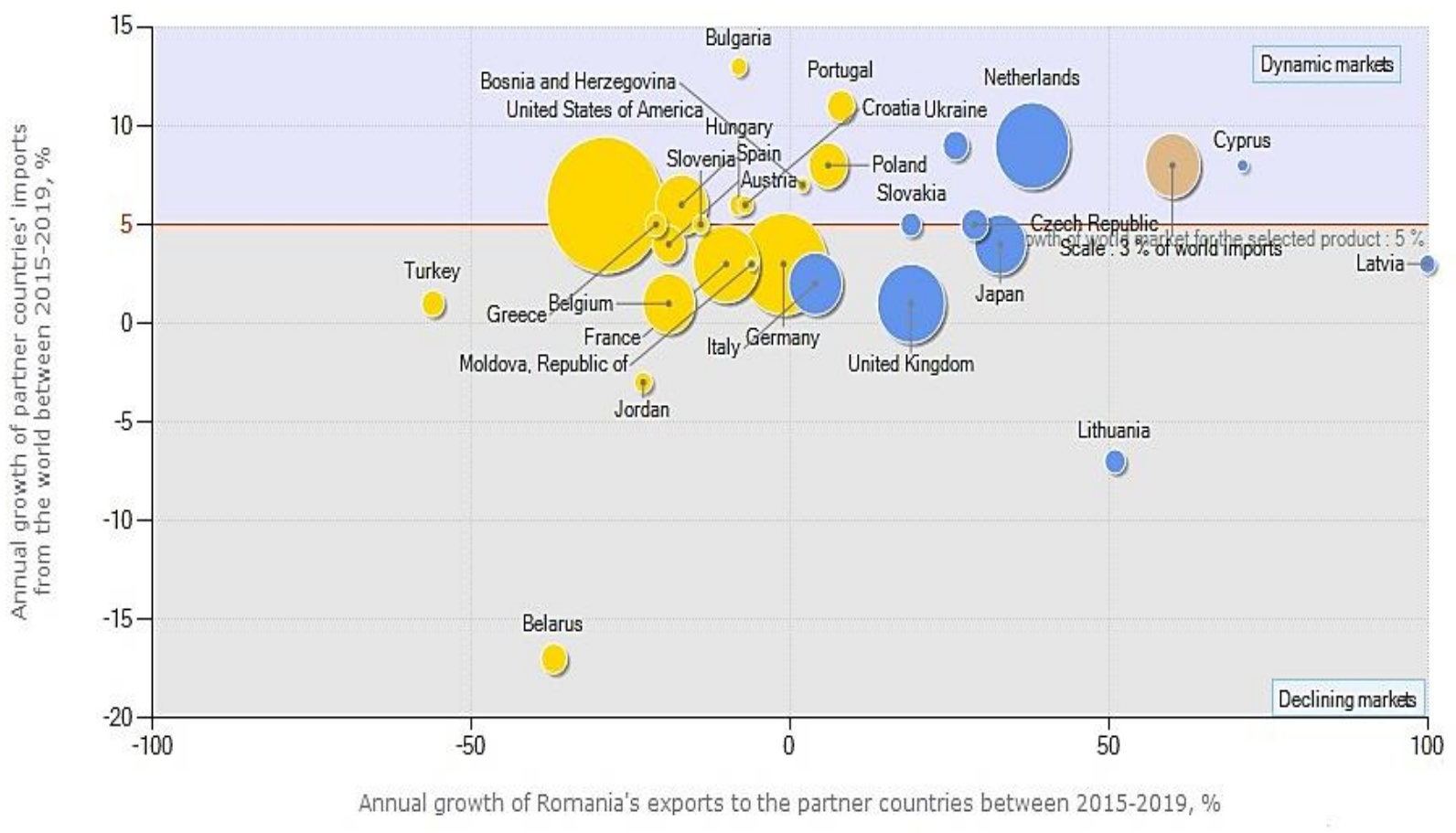

Source: trademap.org, 2021.

DOI: 10.2478/picbe-2021-0078, pp. 849-860, ISSN 2558-9652 |

Proceedings of the $15^{\text {th }}$ International Conference on Business Excellence 2021 


\section{Conclusion}

The world trade of agro-food product has changed in the past few decades due to the increased preference of customers for different type of food. However, food insecurity is expected to increase in the future due to imperfect markets, lack of infrastructure and socio-economic vulnerabilities in the most densely populated and underdeveloped areas. In addition, the negative effects of climate change are increasingly and global agricultural systems are affected. Price volatility can also lead to negative effects. On the other hand, with the help of appropriate public policies that focus on investment, research, innovation, and good agricultural practices, increasing agricultural productivity can be achieved. In this context, international agro-food trade is becoming even more important, than it is. Also for the agro-food sector, these issues are both an opportunity and a challenge. The growth prospects of the agro-food market are a significant advantage for farmers around the world. Companies from countries with a large production capacity and advanced technology are gaining customers annually in front of the companies from developing countries, as Romania. Unfortunately for Romania the agro-food sector is at the same level with the country situation in general, in term of competition with other developed countries. Programs are necessary to support small and medium farmers, encourage young peoples to develop companies for processing food, to reduce imports of finished products. A much greater absorption of European funds is needed for development of technology in agriculture and in the production of prepared food. Another aspect is represented by the financing of investments by banks for Romanian companies from the agro-food sector. Together with the support of banks, the Romanian state is required to provide guarantee funds for these companies in percentages to over from $60 \%$. Also the development of local clusters can be another solution for Romania. Improving legislation for certification and promotion agro-food products, through close dialogue with representatives of relevant associations, and proper budgeting of these programs would help Romanian companies.

\section{References}

Antimiani, Carbone, Constantini and Henke, (2012), "Agri-food exports in the enlarged European Union", Czech Academy of Agricultural Sciences, 58, (8), 354-366.

Barkema, A., Drabenstott, M., Tweeten, L., 1991. The Competitiveness of U.S. Agriculture in the 1990s in agricultural policies. In: Allen, K. (Ed.), the 1990s in Agricultural Policies in the New Decade. Resources for the Future National Planning Association Washington, DC.

Bojnec, and Ferto (2009). "Agro-food trade competitiveness of Central European and Balkan countries" Elseviere, Food Policy, 34, 417-425.

Bułkowska, M. (2015). "The Development of Foreign Trade In Agro-Food Products - The Example Of Poland And Romania", International Conference on Competitiveness of Agro-food and Environmental Economy Proceedings, Vol. 4, 66-75.

Council Competition (2019). ,, Romania's Foreign Trade And Existing Barriers On European Markets”,http://www.consiliulconcurentei.ro/uploads/docs/items/bucket14/id14604/come rtul_exterior_al_romaniei_si_barierele_de_intrare_pe_principalele_piete_europene.pdf.

Ciutacu, Chivu, Andrei (2014), ,Similarities and dissimilarities between the EU agricultural and rural development model and Romanian agriculture. Challenges and perspectives", Elseviere, Land Use Policy, (2015), 169-176.

Dadan, W., Ihle, R., \& Heijma, W. (2017). "Farmer Cooperation in the Context of Agroclusters", ASAE $9^{\text {th }}$ International Conference, 387-419. 
Eurostat Statistics Explained (2018). "International trade of goods", https://ec.europa.eu/eurostat/ statisticsexplained/index.php?title=International_trade_in_goods/ro.

Figiel, S., Kuberska, D., \& Kufel, J. (2012). „New challenges for EU agricultural sector and rural areas", Institute of Agricultural and Food Economics - National Research Institute, 1-17.

International Trade Center, trademap.org.

Lafay, G. (1992). "The measurement of revealed comparative advantages" In: Dagenais, M.G., Plunet, P.-A. (Eds.), International Trade Modelling. Chapman \& Hall, London, 209-236.

PICBE |

860

Ministry of Agriculture and Rural Development (2015). "Strategy for the development of the agro-food sector on medium and long term, horizon 2020-2030", Project, 1-73.

National Committee for Macro prudential Supervision (2020), „Analysis of the CNSM Working Group on reducing vulnerabilities arising from the increase in the trade deficit with agri-food products".

Porutiu, A. (2020). Agro Transilvania Cluster, https://agrocluster.ro/2020/05/28/clusterele-dinsectorul-agroalimentar-din-romania-si-au-reunit-capacitatile-in-cadrul-unei-retele-nationa le-de-clustere/.

Şerbănel, C.I., Cojanu, V. (2016). "Romania and its position on global value chain an introductive analysis", Revista Economică, 68, 193-207.

Zaman, G., \& Georgescu, G. (2018). “A retrospective study on Romania's external trade in the past 100 years", Munich Personal RePEc Archive, MPRA Paper, No. 89707, 1-64.

Zhao, Wang, Pal (2020). "The effect of agro-food supply chains integration on product quality and financial performance: Evidence from Chinese agro-food processing business", International Journal of Production Economics, 231 (2021).

National Institute of Statistics (2020). „International trade in goods in December 2019”, Press Release, Bucharest No. 31/10, https://insse.ro/cms/sites/default/files/com_presa/com_pdf/ ce12r19. 